ЛОКУС: люди, общество, культуры, смыслы. 2020. № 1

DOI: 10.31862/2500-2988-2020-1-33-45

\title{
П.А. Рыбаков
}

Филиал «Угреша» государственного университета «Дубна», 140090 г. Дзержинский Московской области, Российская Федерация

\section{Политика коллективизации и раскулачивания в Рязанском регионе и сопротивление крестьянства ее проведению}

В статье на основе широкого использования документальных архивных материалов, а также материалов прессы представлена политика коллективизации и раскулачивания в Рязанском регионе на рубеже 1920-1930-х гг. Рассматривается процесс выработки политики коллективизации и раскулачивания в данном регионе вкупе с методами их проведения. Подробно анализируются основные формы и методы сопротивления крестьянства аграрной политике государства, их динамика и масштабы. В заключение подводятся итоги проведения коллективизации в Рязанском крае к концу первой пятилетки. Выбор региона связан с тем, что, вследствие своего географического положения (близость к столице), Рязанский край являлся испытательной площадкой для социальноэкономических экспериментов, что придавало событиям особый драматизм, вызывало острую и быструю реакцию крестьянства на проводимые преобразования. Актуальность темы также обусловлена слабой изученностью в исторической литературе политики коллективизации в Рязанском крае.

Ключевые слова: Рязанский регион, коллективизация, раскулачивание, российская деревня, колхозы, крестьянство, налоговая политика в деревне, насилие, репрессии, крестьянское сопротивление

ДЛЯ ЦИТИРОВАНИЯ: Рыбаков П.А. Политика коллективизации и раскулачивания в Рязанском регионе и сопротивление крестьянства ее проведению // Локус: люди, общество, культуры, смыслы. 2020. № 1. С. 33-45. DOI: 10.31862/25002988-2020-1-33-45 


\section{P. Rybakov}

Branch "Ugresha" of Dubna State University, Dzerzhinsky, 140090, Moscow region, Russian Federation

\section{The policy of collectivization and dispossession in the Ryazan region and the resistance of the peasantry to its implementation}

In the article, based on wide use of documentary, archival materials, as well as press materials, the policy of collectivization and dispossession in the Ryazan region at the turn of the 1920s and 1930s is considered. It shows the process of developing a policy of collectivization and dispossession in the studied region, methods of their implementation. The author also analyzes in detail the main forms and methods of resistance of the peasantry to the agrarian policy of the state, their dynamics and scale. In conclusion, the results of the collectivization in the Ryazan region by the end of the first five-year period are summarized. The choice of the region was due to the fact that, thanks to its geographical location (proximity to the capital), this region was a test site for socio-economic experiments, which gave the events a special drama, provoked a sharp and rapid response of the peasantry to the changes being carried out. The relevance of the topic is also caused by the weak study in the historical literature of the policy of collectivization in the Ryazan region.

Key words: collectivization of the Ryazan region, dispossession of kulaks, Russian countryside, collective farms, peasantry, tax policy in the countryside, violence, repression, peasant resistance

FOR CITATION: Rybakov P.A. The policy of collectivization and dispossession in the Ryazan region and the resistance of the peasantry to its implementation. Locus: People, Society, Culture, Meanings. 2020. No. 1. Pp. 33-45. (In Russ.) DOI: 10.31862/2500-2988-2020-1-33-45

В июне 1929 г. была образована Московская область, в состав которой вошли 10 округов, в том числе и Рязанский. Рязанский округ включал Касимовский, Ряжский, Сасовский и Спасский уезды в их полном 
составе, а также части Зарайского, Рязанского и Скопинского уездов. Округ подразделялся на 27 районов [11, с. XXXI].

Состоявшийся в ноябре 1929 г. пленум ЦК ВКП(б) в качестве первоочередной задачи поставил развертывание «сплошной коллективизации» [19, Т. 1, с. 746-764]. По замыслам партийного руководства страны коллективизированная деревня должна была обеспечить бесперебойное снабжение населения быстрорастущих городов необходимым продовольствием, стать источником людских и финансовых ресурсов для нужд индустриализации.

На 1 декабря 1929 г. в Рязанском округе в колхозы было объединено 28 тыс. (или около 7\%) крестьянских хозяйств [14, с. 244]. В декабре того же года Московский областной комитет ВКП(б) под руководством К.Я. Баумана призвал завершить процесс коллективизации в Рязанском округе к весне 1931 г. [16, с. 681]. Но уже в январе 1930 г. на объединенном пленуме МК и МКК ВКП(б) К.Я. Бауман с трибуны озвучил новые цифры и новые сроки для округа: 75\% коллективизированных хозяйств к весне 1930 г. [Там же, с. 682].

После таких установок темпы коллективизации в Рязанском округе стали стремительно расти. Если на 1 января 1930 г. в округе было коллективизировано 10,2\% хозяйств, то к 1 марта - уже 75\% [19, Т. 2, с. 321]. В некоторых районах процент коллективизации был еще выше. К 25 февраля 1930 г. Елатомский район коллективизировал $100 \%$ крестьянских хозяйств, Клепиковский - 98\%, Тумский $-95,5 \%$, Рязанский Южный - 94\%, Старожиловский - 93\%, Пителинский $90,6 \%$, Кораблинский - 84,4\%, Михайловский - 84\%, Ухоловский $80,7 \%$, Ерахтурский - 80,6\%, Рыбновский - 80\%, Ряжский - 79\%, Кадомский - 75,5\% [16, с. 285].

Начавшуюся коллективизацию активно поддерживали многие бедняки и маломощные середняки, нередко даже выступая в роли ее застрельщиков. Так, в поселке Красный Лесок Сараевского района Рязанского округа на собрании крестьян по вопросу о коллективизации бедняк С.Н. Козлов заявил: «Колхоз больше будет давать пользы государству, чем отдельное хозяйство» [Там же, с. 141]. На совещании бедноты Пронского района «все выступающие говорили о трудностях, но считали колхоз единственным путем для улучшения своего благосостояния» [9, с. 160].

Однако большинство крестьян не верили в возможности колхозов и отказывались в них вступать. Поэтому местные работники нередко прибегали к грубому нажиму, насилию, угрозам, арестам. Так, в селе Алексеевка Сараевского района, проводя собрание по коллективизации, член бригады Шурчков обратился к присутствующим с такими словами: «Ваша деревня - кулацкая, упорно не идет в колхоз. У вас сплошь все 
контрреволюционеры и кулаки, которые агитируют против колхозов» [12]. Тем, кто молчал на собрании, Шурчков говорил: «Ты враг мне и всем колхозникам» и запугивал людей так, что их «бросало в пот» [Там же]. Его угрозы возымели действие: сразу после собрания село стало «коллективизированным» на 80\% [Там же]. В селе Зимино Захаровского района уполномоченный по коллективизации Давыдов, придя на собрание, вынимал из кармана наган и клал его на стол. За выступление против колхоза он арестовал двух женщин-беднячек и отправил их в районный административный отдел (милицию), где их продержали двое суток [16, с. 228]. В селе Ново-Чернеево Шацкого района работники сельсовета и уполномоченный райисполкома вызывали всех не вступивших в колхоз крестьян в отдельную комнату и «делали внушение» в виде угроз и запугиваний. В результате все село было коллективизировано, но настроение у крестьян «плохое» [Там же, с. 240]. В селе Калиновец Сасовского района уполномоченные по коллективизации Мясников, Сморчков и Дыков применяли грубый подход к населению: не желавших вступать в колхоз середняков вызывали и грозили отбором всего имущества и всевозможными репрессиями [Там же, с. 324].

К крестьянам, сопротивлявшимся вступлению в колхозы, применяли методы экономического нажима. В Кадомском, Пителинском, Александро-Невском и Северо-Рязанском районах по отдельным селениям лишали не вступивших в колхозы крестьян снабжения необходимыми товарами. В Сасовском районе руководство районной кооперативной базы распорядилось прекратить отпуск соли, керосина и других необходимых товаров всем крестьянам, не вступавшим по тем или иным причинам в колхоз [15, с. 13]. В Ермишинском, Пителинском, Шацком и Пронском районах в качестве воздействия к не вступившим в колхозы у них производились обыски с последующим изъятием (под видом сбора семфонда) всех зерновых, хлебных и фуражных запасов, налагались штрафы [16, с. 411].

Факты грубого администрирования при организации колхозов постоянно фиксировались органами Объединенного государственного политического управления (ОГПУ). Так, в одной из спецсводок Рязанского окротдела ОГПУ от 8 марта 1930 г. говорилось: «Во всех положительно районах за основу работы по колхозстроительству работники мест брали нажим, администрирование, подменяя во многих случаях ими полностью агитразъяснительную работу. Многие уполномоченные, бригадники и сельсоветчики перегибали палку, как средством вовлечения в колхоз пользуясь запугиванием, арестами, экономическим нажимом» [Там же, с. 397]. Случаи насильственной организации колхозов, в том числе и в Рязанском округе, отмечал и руководитель Московской 
областной организации К.Я. Бауман на III Пленуме МК ВКП(б) в марте 1930 г.: «Мы в ряде случаев, в ряде организаций имели явное попрание принципа добровольности... Например, в Ряжском районе Рязанского округа уполномоченный грозил населению лишением земли, ссылкой в Соловки, арестами за отказ войти в колхоз» [4, л. 71 об.].

Одновременно с коллективизацией на основании Постановления Политбюро ЦК ВКП(б) «О мероприятиях по ликвидации кулацких хозяйств в районах сплошной коллективизации» от 30 января 1930 г. [20, с. 126-130] проводилась политика раскулачивания. В Рязанском округе она началась еще до выхода данного постановления. К 30 января только по шести районам Рязанского округа (Александро-Невский, Кораблинский, Пронский, Рыбновский, Ряжский, Старожиловский) было раскулачено 243 хозяйства [16, с. 161, 164-166]. Всего к середине февраля 1930 г., по сведениям секретаря Рязанского окружного комитета партии Н.Т. Тимофеева, в округе было раскулачено 1827 хозяйств [18, л. 63].

Еще в начале января 1930 г., выступая на объединенном пленуме МК и МКК ВКП(б), первый секретарь Московского областного комитета партии К.Я. Бауман давал следующие указания при проведении раскулачивания: «На основе постановления большинства деревни в районах сплошной коллективизации возможна полная или частичная экспроприация средств производства у кулака и передача их в неделимый фонд колхозов с последующим отведением раскулаченному кулаку худших земель на окраине или его выселением на другие, незанятые земли, или его использованием в качестве рабочей силы. Придется также в борьбе с злостно сопротивляющимся кулаком применять и прямые меры государственных репрессий, арестов, высылок, расстрелов и т.д.» [2, с. 11]. Похожие инструкции в отношении кулачества давались и на совещании секретарей райкомов ВКП(б) Рязанского округа в январе 1930 г.: «Я считаю, что надо кулаков выселять из их домов, а все имущество оставлять в доме» (секретарь Александро-Невского района тов. Туткин); «Мы кулакам не даем никакой земли - ни хорошей, ни плохой - и применяем больше всего метод выселения их из района» (секретарь Елатомского района тов. Чвоков) [16, с. 162]; «Мы считаем, что его [кулака] нужно заставить работать на пользу нам, посадить его на плохую землю, пусть он ее обрабатывает» (секретарь Ряжского района тов. Сморчков) [Там же, с. 166].

Подобные указания приводили к тому, что процесс раскулачивания нередко оборачивался обыкновенным грабежом, когда у раскулаченных производился отбор практически всех вещей. Так, бригады сёл Верея, Прудки и Дунино Клепиковского района при проведении 
раскулачивания отбирали у крестьян такие вещи, как постельные принадлежности (часто единственные), посуду, сало, моченые яблоки, варенье и т.д. [16, с. 275]. В селе Дубровичи Северо-Рязанского района в отдельных случаях дело доходило до отбора икон, детских игрушек [7]. В деревне Веряево Пителинского района в списки изъятых у кулаков вещей попадали деревянные гребешки, юбки, портянки, пеленки и т.д. [15, с. 14]. Подобные факты признавало и окружное руководство. Выступая на совещании секретариата МК ВКП(б) 19 февраля 1930 г., руководитель Рязанского округа Н.Т. Тимофеев отмечал: «Раскулачивали кулацкие хозяйства так, что иногда им буквально ничего не оставляли» [18, л. 64].

Во многих районах округа раскулачивание проводилось часто ночью, в некоторых случаях выставлялись вооруженные заставы, дежурили патрули. Так, с 14 по 16 февраля 1930 г. в селе Черная Речка Сапожковского района раскулачивание проводилось ночами. На селе создалась паника. Крестьяне начали прятать имущество, зарывая его в сено, в навоз и просто в снег. Утром собаки таскали по улицам спрятанное по дворам мясо [16, с. 241]. В деревне Киселевка Южно-Рязанского района приехавший по заданию РИКа и РК ВКП(б) для раскулачивания начальник районного административного отдела Балашкин расставил на выходах из села пятерых привезенных с собой милиционеров, собрал бедноту и без всякого разъяснения заявил им, что приехал раскулачивать. Собранная беднота в панике разбежалась и бросилась прятать имущество [Там же].

Раскулачивание, осуществляемое форсированно и повсеместно, затронуло не только кулаков, но и средние и бедные слои деревни, служащих, интеллигенцию. Так, в селе Кидусово Северо-Рязанского района рабочая бригада раскулачила 13 хозяйств, из коих попали под раскулачивание «один рабочий, три середняка, врач, фельдшерица и две учительницы» [16, с. 233]. Детей раскулачиваемых выбрасывали в холодные недостроенные помещения. В деревне Студеновка Шацкого района 20 февраля раскулачили середняка Ф.В. Ширенина. При раскулачивании у него были отобраны лошадь, корова и все хлебопродукты. Производивший раскулачивание председатель коммуны С. Ширенин говорил: «Раскулачили за то, что имел каменный амбар» [Там же, с. 325]. В селе Кривском Сараевского района раскулачили и постановили выселить за пределы района двух крестьян-бедняков за то, что они в раннем детстве были подкинуты к кулаку и воспитывались у него до 1918 г. [Там же, с. 370]. В селе Дубровичи Северо-Рязанского района раскулачили старуху, которая давно перешла со всем своим имуществом в хозяйство одной беднячки-колхозницы. Старуху раскулачили за то, 
что до 1905 г. она имела небольшую торговлю [7]. По сведениям Рязанского окротдела ОГПУ, в январе 1930 г. по округу было зарегистрировано 17 случаев раскулачивания середняков, бедняков и интеллигенции, а в феврале уже 36 случаев [16, с. 275,325$]$.

Насильственная коллективизация и раскулачивание вызвали массовое недовольство и решительное сопротивление крестьянства, которое принимало как пассивные, так и активные формы.

Одной из наиболее распространенных пассивных форм протеста против коллективизации были убой и распродажа скота. В Рязанском округе убой и распродажа скота тоже приняли широкие масштабы, что постоянно отражалось в сводках ОГПУ. Так, в спецсводке Рязанского окротдела ОГПУ о ходе сплошной коллективизации от 14 января 1930 г. сообщалось: «Во многих селах продажа и убой принимают массовый характер» [Там же, с. 133]. В спецсводке приводились и конкретные случаи. Так, в селе Волынь Северо-Рязанского района в связи с коллективизацией происходил массовый убой скота. Всего было продано и зарезано 82 головы крупного и мелкого скота и лошадей [Там же, с. 138]. В селе Константиново Рыбновского района с 1 декабря 1929 г. было продано и зарезано «лошадей - 20 штук, коров - 70 штук, овец - 150 штук, свиней - 150 штук. У населения одно рассуждение: “Надо продавать, чем отдавать даром колхозу”» [Там же, с. 139]. В Ряжском районе количество голов скота (и мелкого, и крупного) сократилось на 20,1\%. Если на 1 мая 1929 г. насчитывалось 4926 голов, то на 1 января 1930 г. осталось всего 3940. Снижение поголовья происходило за счет продажи и убоя скота и приходилось в основном на два последних месяца [Там же].

Сопротивление крестьянства государственному насилию в деревне перерастало во многих районах страны в массовые стихийные выступления, которые нередко выливались в вооруженные восстания. Однако эти выступления носили, как правило, локальный характер, были слабо организованы, чаще всего охватывали население одной или нескольких деревень, входивших в состав сельсовета, района, реже - нескольких районов. Массовые выступления были зафиксированы и в Московской области, в том числе в Рязанском округе. В мартовской справке информационного отдела ОГПУ по Московской области сообщалось: «В Рязанском округе антиколхозное движение приобрело особенную остроту, охватило десятки селений и сопровождалось убийствами и избиением местных работников и вооруженным сопротивлением оперативным группам, высылаемым для изъятия контрреволюционного и кулацкого элемента» [19, Т. 2, с. 324]. В период с января по середину марта 1930 г. в Рязанском округе на почве коллективизации произошло 
77 выступлений с общим количеством участников 25082 человека [19, Т. 2, с. 326]. По количеству массовых выступлений Рязанский округ значительно опережал все другие округа Московской области [Там же].

Так, 19-20 февраля 1930 г. произошло выступление крестьян Казачьей и Черной Слобод Шацкого района, спровоцированное грубыми действиями местных работников при создании семфонда, а также неправильным раскулачиванием [16, с. 254]. Комсомольцы и бригадники при ссыпке семфонда вели себя грубо и вызывающе. Приехав к середняку Стрельникову, они кричали на него: «Отпирай амбар, сейчас будем все ссыпать». Бригадир Кургузов ударил кулаком по лицу женщину, которая препятствовала ему забирать семена. В селе Черной [Черная Слобода] было раскулачено несколько середняков; в частности, «у середняков Пентелькова и Селиванова было отобрано все до нитки» [Там же, с. 255]. Выступление, в котором участвовало до 300 человек, главным образом женщины, сопровождалось избиениями бригадиров, милиционеров. Волнение улеглось только после того, как ссыпка семфонда была прекращена [Там же].

Одним из самых массовых выступлений было выступление крестьян Пителинского района 22-26 февраля 1930 г. События начались 22 февраля 1930 г. в селе Веряево во время кампании по обобществлению семян. В ходе кампании отбирали не только семена, но и печеный хлеб. Восставших поддержали крестьяне соседних селений. В общей сложности в Пителинском и Тумском районах движением было охвачено 42 населенных пункта, а участвовало в беспорядках более 12 тыс. человек. Были разгромлены амбары с ссыпанным семенным зерном, поломан инвентарь, растащен амбар с отобранными при раскулачивании вещами. За время волнений были убиты трое и ранены шесть сельчан, убит работник уголовного розыска, ранено восемь активистов [1, с. 89-90].

Другой острой формой протеста были террористические и диверсионные акты крестьянства против коммунистов, работников низового советского аппарата, сельских активистов и колхозников. По данным ОГПУ, в период с 1 января по 18 марта 1930 г. в Рязанском округе было зафиксировано 35 терактов. По виду совершаемых действий они распределялись следующим образом: убийства - 2 случая; покушения на убийство, избиения, ранения - 22; поджоги - 9; имущественные вредительства - 2 случая [19, Т. 2, с. 327].

Весьма распространенным методом активного политического сопротивления крестьянства являлся выпуск листовок и анонимок антиколхозного содержания. За период с января по середину февраля 1930 г. 
в Московской области было выявлено 40 случаев распространения подобных листовок. Из них 14 листовок было учтено в Рязанском округе [17, с. 692]. Так, в селе Ирицы Шиловского района 7 февраля было обнаружено 4 экземпляра листовки со следующим призывом: «Товарищи, не ходите в колхоз, на весну будет война, и всех колхозников и коммунистов, комсомол будем вешать, обливать керосином и жечь. Товарищи, не ходите в колхоз, а дайте отпор коммунисту. Долой коммунизм и комсомол и его прихвостников!» [Там же, с. 701].

Массовое недовольство крестьян насильственной коллективизацией заставило руководство страны несколько ослабить нажим. 14 марта 1930 г. вышло Постановление ЦК ВКП(б) «О борьбе с искривлениями партийной линии в колхозном движении», в котором ЦК потребовал от парторганизаций прекратить насильственную коллективизацию и исправить допущенные ошибки [19, Т. 2, с. 303-305]. Ошибки в деле колхозного строительства признавало и руководство Рязанского края. Выступая на пленуме окрисполкома в конце марта, уже новый руководитель Рязанского окружкома Ф.И. Козлов говорил: «Надо откровенно сказать, что во многих районах применялись безобразные методы коллективизации и раскулачивания. <...> Мало заботились о том, чтобы создать действительно прочные колхозы на основе добровольности, а гнались больше за количеством коллективных хозяйств. Раскулачивание проводилось без привлечения широчайших бедняцко-середняцких масс. В число раскулаченных подчас попадали середняки и даже бедняки» [10].

Кроме того, многие местные работники и организации были наказаны за «перегибы», допущенные в ходе сплошной коллективизации. К середине апреля 1930 г. в Рязанском округе было распущено 15 сельсоветов и партийных организаций, 64 человека уволены с работы, 23 районных руководителя и 131 человек сельских руководителей были привлечены к суду, более 10 человек окружного руководства лишились своих должностей в Московской области. 18 апреля 1930 г. с поста секретаря МК ВКП(б) был уволен К.Я. Бауман [3, с. XL].

Выход постановления ЦК от 14 марта привел к массовому оттоку крестьян из колхозов, который продолжался в течение нескольких месяцев. К 1 июня 1930 г. доля коллективизированных хозяйств в Рязанском округе составляла всего 8\%, а на 10 августа - 7,9\% [5, л. 59]. В колхозах остались в основном бедняки и маломощные середняки, которые, вступая в колхозы, надеялись с помощью государства улучшить свое бедственное положение.

Однако уже осенью 1930 г., несмотря на массовое недовольство крестьянства, ЦК ВКП(б) потребовал возобновить коллективизацию. 
Состоявшийся в феврале 1931 г. V Пленум МК ВКП(б) поставил задачу довести уровень коллективизации в районах деятельности МТС до $40-50 \%$ [13, с. 447].

Между тем многие крестьяне по-прежнему отказывались идти в колхозы. Так, в Сараевском районе при обсуждении вопроса о коллективизации бедняк Арбатский говорил: «Пусть колхоз организуют те, кто хочет, я же лучше удавлюсь, но в колхоз не пойду» [6, с. 433]. Подобные настроения приводили к тому, что в отношении не желающих вступать в колхозы крестьян вновь стали широко использоваться угрозы и репрессии.

В 1931 г. была продолжена и политика раскулачивания. Так, в апреле 1931 г. из Рязанского района было выселено 78 хозяйств (435 человек). В ночь с 13 на 14 июля в том же районе было арестовано 228 кулаков (главы семей), а затем репрессированы и остальные члены их семей. В начале августа из района были выселены еще 92 кулацкие семьи [9, с. 145].

На конец 1932 г. уровень коллективизации в Московской области составлял всего 53,4\% [Там же, с. 210]. В Рязанском крае он был еще ниже. Самые высокие показатели имели Шацкий район, где в колхозы было объединено 55\% крестьянских хозяйств, и Рязанский район с уровнем коллективизации в 50\%. Самые низкие показатели были у Ермишинского района - около 35\% [8, с. 62].

Таким образом, колхозное движение в Рязанском крае имело противоречивый и драматичный характер. Наряду с добровольным движением крестьян в колхозы использовались принудительные и насильственные методы вовлечения крестьян в колхозы, причем при явном преобладании последних. Ответной реакцией крестьянства на проведение политики сплошной коллективизации и раскулачивания становились протесты, принимавшие как пассивные, так и активные формы. Однако массовые протесты крестьян не смогли помешать планам центрального руководства страны и местных властей довести коллективизацию до конца. К концу первой пятилетки в колхозы региона было объединено около половины крестьянских хозяйств.

\section{Библиографический список / References}

1. Агарев А.Ф., Курышкин В.П. Рязанская история в событиях и лицах (1917-1993 гг.). Рязань, 2016. [Agarev A.F., Kuryshkin V.P. Ryazanskaya istoriya v sobytiyakh i litsakh (1917-1993 gg.) [Ryazan history in events and persons (1917-1993)]. Ryazan, 2016.]

2. Бауман К.Я. Социалистическое наступление и задачи Московской организации. Доклад на объединенном Пленуме МК и МКК ВКП(б), 6-10 января 
1930 г. // Объединенный Пленум Московского комитета и Московской контрольной комиссии ВКП(б), 6-10 января 1930 г. М., 1930. С. 3-48. [Bauman K.Ya. Socialist offensive and the tasks of the Moscow organization. Report at the joint Plenum of the Moscow Committee and the Moscow Control Commission of the CPSU (B.), January 6-10, 1930. Ob"yedinennyy Plenum Moskovskogo komiteta i Moskovskoy kontrol'noy komissii VKP(b), 6-10 yanvarya $1930 \mathrm{~g}$. Moscow, 1930. Pp. 3-48. (In Russ.)]

3. Виола Л. Коллективизация и Рязанский округ. 1929-1930 гг. // Рязанская деревня в 1929-1930 гг.: Хроника головокружения. Документы и материалы. M., 1998. C. XXXIII-XLV. [Viola L. Collectivization and the Ryazan District. 1929-1930. Ryazanskaya derevnya v 1929-1930 gg.: Khronika golovokruzheniya. Dokumenty i materialy. Moscow, 1998. Pp. XXXIII-XLV. (In Russ.)]

4. Доклад тов. Баумана о весенней посевной кампании на III Пленуме МК ВКП(б), 26-28 марта 1930 г. // Российский государственный архив социально-политической истории. Ф. 17 (ЦК ВКП(б)). Оп. 20. Д. 210. Л. 63-100. [Report Comrade Bauman on the spring sowing campaign at the III Plenum of Moscow Committee of the CPSU(B.), March 26-28, 1930. Russian State Archive of Socio-Political History (RGASPI). Fund 17 (Central Committee of the CPSU(B.) VKP(b)). Inventory 20. Case 210. Sheets 63-100. (In Russ.)]

5. Докладная записка о недочетах колхозного строительства по Московской области (по материалам на 25 августа 1930 г.) // Центральный государственный архив города Москвы. Отдел хранения документов общественно-политической истории Москвы. Ф. 3 (Московский комитет ВКП(б)). Оп. 11. Д. 901. Л. 28-59. [Memorandum on the shortcomings of collective farm construction in the Moscow region (based on materials as of August 25, 1930). The Central State Archive of the City of Moscow. Department of Document Storage of the Socio-political History of Moscow. Fund 3 (Moscow Committee of the CPSU(B.)). Inventory 11. Case 901. Sheets 28-59. (In Russ.)]

6. Документы свидетельствуют. Из истории деревни накануне и в ходе коллективизации, 1927-1932 гг. / Под ред. В.П. Данилова, Н.А. Ивницкого. М., 1989. [Dokumenty svidetel'stvuyut: Iz istorii derevni nakanune i v khode kollektivizatsii, 1927-1932 gg. [Documents testify: From the history of the village on the eve and in the course of collectivization, 1927-1932]. V.P. Danilova, N.A. Ivnitsky (eds.). Moscow, 1989.]

7. Емельянов Д. Вредные перегибы // За коллективизацию. 1930. № 29 (779). 7 марта. [Yemel'yanov D. Harmful excesses. Za kollektivizatsiyu. 1930. No. 29 (779). March 7. (In Russ.)]

8. Кирьянова Е.А. Деревня Центра России в 1933-1937 годах: социальноэкономическое и политическое развитие. Рязань, 2004. [Kir'yanova Ye.A. Derevnya Tsentra Rossii v 1933-1937 godakh: sotsial'no-ekonomicheskoye i politicheskoye razvitiye [Village of the Center of Russia in 1933-1937: Socioeconomic and political development]. Ryazan, 2004.]

9. Кирьянова Е.А. Коллективизация деревни Центра России (19291932 годы). Рязань, 2006. [Kir'yanova Ye.A. Kollektivizatsiya derevni Tsentra Rossii (1929-1932 gody) [Collectivization of the village of the Center of Russia (1929-1932)]. Ryazan, 2006.]

10. Козлов Ф.И. Выступление на расширенном пленуме окрисполкома. 23 марта 1930 г. // Ленинский путь. 1930. № 71. [Kozlov F.I. Speech 
at the enlarged plenum of the executive committee. March 23, 1930. Leninskiy put’. 1930. № 71. (In Russ.)]

11. МакДоналд Т. Из прошлого рязанской деревни // Рязанская деревня в 1929-1930 гг.: Хроника головокружения. Документы и материалы. М., 1998. С. XXII-XXXII. [MakDonald T. From the past of the Ryazan village. Ryazanskaya derevnya v 1929-1930 gg.: Khronika golovokruzheniya. Dokumenty i materialy. Moscow, 1998. Pp. XXII-XXXII. (In Russ.)]

12. Образец беззакония // Крестьянская газета. 1930. № 30. 16 апреля. [Sample of lawlessness. Krest'yanskaya gazeta. 1930. No. 30. April 16. (In Russ.)]

13. Очерки истории Московской организации КПСС. Кн. 2. Ноябрь 1917-1945. M., 1983. [Ocherki istorii Moskovskoy organizatsii KPSS. Kniga 2. Noyabr' 1917-1945 [Essays on the history of the Moscow organization of the CPSU. Book 2. November 1917-1945]. Moscow, 1983.]

14. Очерки истории Рязанской организации КПСС. М., 1974. [Ocherki istorii Ryazanskoy organizatsii KPSS [Essays on the history of the Ryazan organization of the CPSU]. Moscow, 1974.]

15. Попов П. «В два счета» коллективизировали деревню // Коллективист. 1930. № 6. C. 13-14. [Popov P. "In two accounts" collectivized the village. Kollektivist. 1930. No. 6. Pp. 13-14. (In Russ.)]

16. Рязанская деревня в 1929-1930 гг.: Хроника головокружения. Документы и материалы. М., 1998. [Ryazanskaya derevnya v 1929-1930 gg.: Khronika golovokruzheniya. Dokumenty i materialy [Ryazan village in 1929-1930: Chronicle of dizziness. Documents and materials]. Moscow, 1998.]

17. «Совершенно секретно»: Лубянка - Сталину о положении в стране (1932-1934 гг.): Сб. документов. Т. 8: 1930. Ч. 1. М., 2008. [«Sovershenno sekretno»: Lubyanka - Stalinu o polozhenii v strane (1932-1934 gg.) [“Top Secret": Lubyanka - to Stalin about the situation in the country (1932-1934)]. Collection of documents. Vol. 8: 1930. Part 1. Moscow, 2008.]

18. Стенограмма совещания при секретариате МК ВКП(б) о ходе весенней посевной кампании и коллективизации в Московской области 19 февраля 1930 г. // Центральный государственный архив города Москвы. Отдел хранения документов общественно-политической истории Москвы. Ф. 3. Оп. 12. Д. 136. Л. 63-66. [Transcript of the meeting at the secretariat of Moscow Committee of the CPSU(B.) on the progress of the spring sowing campaign and collectivization in the Moscow Region on February 19, 1930. The Central State Archive of the City of Moscow. Department of Document Storage of the Socio-political History of Moscow. Fund 3. Inventory 12. Case 136. Sheets 63-66. (In Russ.)]

19. Трагедия советской деревни. Коллективизация и раскулачивание. 1927-1939: документы и материалы: в 5 т. Т. 1. Май 1927 - ноябрь 1929. М., 1999. Т. 2. Ноябрь 1929 - декабрь 1930. М., 2000. [Tragediya sovetskoy derevni. Kollektivizatsiya i raskulachivaniye. 1927-1939. Dokumenty i materialy [The tragedy of the Soviet village. Collectivization and dispossession. 1927-1939. Documents and materials]. In 5 vols. Vol. 1. May 1927 - November 1929. Moscow, 1999. Vol. 2. November 1929 - December 1930. M., 2000.] 
О6 авторе / About the author

Рыбаков Павел Александрович - кандидат исторических наук; доцент кафедры общеобразовательных дисциплин, филиал «Угреша» Государственного университета «Дубна», г. Дзержинский Московской области

Pavel A. Rybakov - PhD in History; Associate Professor at the Department of General Education, Branch "Ugresha" of Dubna State University, Dzerzhinsky, Moscow region

E-mail: rybakov_ok@mail.ru 